\title{
Synthesis, Antibacterial and Antioxidant Evaluation of Novel 1-(5,7-Dichloro-1,3-benzoxazol-2-yl)-1 $H$-pyrazolo[3,4-b]quinoline Derivatives
}

\author{
N. D. Jayanna, ${ }^{1}$ H. M. Vagdevi, ${ }^{1}$ J. C. Dharshan, ${ }^{2}$ and T. R. Prashith Kekuda ${ }^{3}$ \\ ${ }^{1}$ Department of Chemistry, Sahyadri Science College, Shimoga 577 203, India \\ ${ }^{2}$ Department of PG Studies and Research in Industrial Chemistry, Sir M.V. Government Science College, Bommanakatte, \\ Bhadravathi 577451, India \\ ${ }^{3}$ Department of Microbiology, Sahyadri Science College, Shimoga 577 203, India
}

Correspondence should be addressed to H. M. Vagdevi; vagdevihm@gmail.com

Received 18 May 2013; Accepted 5 August 2013

Academic Editor: Ponnurengam Malliappan Sivakumar

Copyright (C) 2013 N. D. Jayanna et al. This is an open access article distributed under the Creative Commons Attribution License, which permits unrestricted use, distribution, and reproduction in any medium, provided the original work is properly cited.

\begin{abstract}
Some novel 1-(5,7-dichloro-1,3-benzoxazol-2-yl)-1H-pyrazolo[3,4- $b$ ]quinoline derivatives 8 (a-f) were synthesized by reacting 5,7dichloro-2-hydrazino-1,3-benzoxazole 4 and substituted-2-chloro-3-quinoline carbaldehydes using $p$-toluenesulfonic acid (PTSA) as a catalyst for the cyclisation. The target molecules have been characterized by $\mathrm{IR},{ }^{1} \mathrm{H} \mathrm{NMR},{ }^{13} \mathrm{C} \mathrm{NMR}$, and mass spectral studies. The synthesized compounds were screened for biological activities, and some of the compounds have exhibited encouraging antibacterial and antioxidant activities. The compounds $\mathbf{8} \mathbf{a}$ and $\mathbf{8 e}$ showed potent antibacterial activity, whereas the compounds $\mathbf{8 e}$ and $\mathbf{8} \mathbf{f}$ act as antioxidants.
\end{abstract}

\section{Introduction}

Both benzoxazole and quinoline derivatives have their own impact in the field of medicine. The benzoxazoles have attracted the researchers for many years because they constitute an important class of heterocyclic compounds [1]. The oxazole-containing heterocyclic compounds play an imperative role in medicinal chemistry and exhibit wide range of biological activities like antimicrobial [2-5], CNS, antihyperglycemic potentiating, analgesic, and anti-inflammatory activities [6]. 2-Substituted benzoxazoles [7] were prominently studied trusting that this position is influential for the biological activity, whereas substitutions at position 5 potentiate the activity.

Pyrazole and its derivatives are gaining importance in medicinal and organic chemistry. They have displayed a broad spectrum of pharmacological and biological activities such as antibacterial, antidepressant, and antihyperglycemic activities [8]. Quinoline derivatives are found to possess antimalarial, anti-inflammatory, antituberculosis, and antibreast cancer activities [9]. Keeping in view the potential biological activities of the pyrazoles and quinolines, the chemists have tried to synthesize and evaluate bioactivities of molecules having these ring systems in a molecular frame work as infused or bonded forms. One such form is pyrazolo[3,4-b]quinolines, which have displayed bioactivities [10]. Considering the applicability of pyrazolo[3,4-b]quinolines, several attempts are made to provide convenient synthetic routes. The literature reveals that the widely used methods for obtaining the pyrazolo[3,4-b]quinolines are using 2-chloro-3-formyl quinolines as precursors/starting materials. In one of the routes, the 2-chloro-3-formyl quinolines have been condensed with hydrazine hydrate/phenyl hydrazine in refluxed ethanol and obtained moderate yields of the pyrazolo[3,4-b]quinolines [11]. The neat one-pot condensation of the 2-chloro-3-formyl quinolines and hydrazine hydrate/phenyl hydrazine using organic catalyst, P-TSA, under microwave has also been reported [12]. It has been recorded that in these routes the products, pyrazolo[3,4b] quinolines, obtained were not found to be pure and were always accompanied with intermediate Schiff bases, 1-[(2chloroquinolin-3-yl)methylene]hydrazines/1-[(2-chloroquinolin-3-yl)methylene]-2-phenylhydrazines. 
Encouraged by the literature reports and to assess the pharmacological profile of such class of compounds, it was thought to construct the benzoxazole nucleus linked with quinolines, which may impart enhanced biological activity. In the present study, we have synthesized novel substituted benzoxazoles fused with quinoline pyrazole, subjected to antimicrobial and antioxidant activities.

\section{Experimental Studies}

2.1. Chemistry. Melting points were recorded on electro-thermal melting point apparatus and are uncorrected. ${ }^{1} \mathrm{H} \mathrm{NMR}$ and ${ }^{13} \mathrm{C}$ NMR spectra were recorded on Bruker $400 \mathrm{MHz}$ spectrometer in IISc, Bangalore, Karnataka, India. The chemical shifts are shown in $\delta$ values (ppm) with tetramethylsilane (TMS) as an internal standard. LC-MS was obtained using C 18 column on Shimadzu, LCMS 2010A, Japan. The FTIR spectra of the compounds were taken in $\mathrm{KBr}$ pellet (100 mg) using Shimadzu Fourier Transformed Infrared (FTIR) Spectrophotometer. The column chromatography was performed using silica gel (230-400 mesh). Silica gel GF254 plates from Merck were used for TLC, and spots were located either by UV or dipping in potassium permanganate solution. The chemicals were purchased from Sigma-Aldrich Co and from SD Fine chemicals. The solvents for column chromatography were of reagent grade and were purchased from commercial source.

(i) For Preparation of 2-Chloroquinoline-3-carbaldehyde 6(af). See [13].

(ii) Preparation of 5,7-Dichloro-1,3-benzoxazole-2-thiol (1). Methanol $(50 \mathrm{~mL})$ and potassium hydroxide (1.1eq) were stirred for $10 \mathrm{~min}$ and followed by slow addition of carbon disulphide (1.1eq) at room temperature. To the reaction mass, 2-amino-4,6-dichlorophenol (1.eq) was added with stirring. The reaction mass was refluxed for $6 \mathrm{hr}$ on water bath. The completion of the reaction was monitored by TLC. The reaction mass was poured onto ice-cold water and acidified with glacial acetic acid ( $\mathrm{pH}$ ). The obtained solid was filtered, dried, and recrystallized using ethanol.

(iii) Preparation of 5,7-Dichloro-2-(ethylthio)-1,3-benzoxazole (2). To a mixture of sodium hydroxide $(10 \mathrm{mmol})$ and compound 1 (10 mmol) in dimethyl sulphoxide $(10 \mathrm{~mL})$, ethyl iodide $(10 \mathrm{mmol})$ was added dropwise. The reaction mass was stirred for about $1 \mathrm{hr}$, and the completion of the reaction was confirmed by TLC. The reaction mass was poured on to icecold water, and the obtained solid filtered, was dried, and recrystallized using hexane.

Brown color solid, Yield (90\%), M.P. $38-39^{\circ} \mathrm{C}$; IR (KBr) $\nu_{\max } \mathrm{cm}^{-1}: 2974(\mathrm{CH}$ alkyl), $1608(\mathrm{C}=\mathrm{N}), 1491(\mathrm{C}=\mathrm{C}), 756(\mathrm{C}-$ $\mathrm{Cl}) ;{ }^{1} \mathrm{H}$ NMR $\left(\mathrm{CHCl}_{3}\right)$ ppm: $\delta 1.4\left(\mathrm{t}, 3 \mathrm{H}, \mathrm{CH}_{3}\right), \delta 3.26(\mathrm{q}$, $\left.2 \mathrm{H}, \mathrm{CH}_{2}\right), \delta 7.1$ (s, 1H, Ar), and $\delta 7.4$ (s, $\left.1 \mathrm{H}, \mathrm{Ar} \mathrm{H}\right) ;{ }^{13} \mathrm{C} \mathrm{NMR}$ $\left(\mathrm{CHCl}_{3}\right): \delta 13.22\left(\mathrm{CH}_{3}\right), 14.29\left(\mathrm{CH}_{2}\right), 108.2,116.5,122.4,128.3$, 129.62, 140.7, and 153.2; MS: $\left(\mathrm{M}^{+}\right) \mathrm{m} / z 248, \mathrm{~m} / \mathrm{z}^{+2} 250, \mathrm{~m} / \mathrm{z}^{+4}$ 252; Anal. Calcd for $\mathrm{C}_{9} \mathrm{H}_{7} \mathrm{Cl}_{2} \mathrm{NOS}$ (248.1): C 43.56, $\mathrm{H} 2.84$, and N 5.64; Found: C 43.55, H 2.82, and N 5.62. (iv) Preparation of 5,7-Dichloro-2-hydrazino-1,3-benzoxazole (3). The compound $3(10 \mathrm{mmol})$ was taken in a round bottomed flask, treated with hydrazine hydrate $(15 \mathrm{mmol})$ in ethanol $(15 \mathrm{~mL})$, and refluxed for $3 \mathrm{hr}$. The reaction mixture was cooled and filtered. The obtained solid was recrystallized from ethanol.

Brown color, pluffy solid, Yield (70\%), M.P. 220-222 ${ }^{\circ}$; IR $(\mathrm{KBr}) v_{\max } \mathrm{cm}^{-1}: 3349\left(\mathrm{NH}_{2}\right), 3283(\mathrm{NH}), 1617(\mathrm{C}=\mathrm{N}), 1453$ $(\mathrm{C}=\mathrm{C})$, and $771(\mathrm{C}-\mathrm{Cl}) ;{ }^{1} \mathrm{H}$ NMR (DMSO- $\left.d_{6}\right) \mathrm{ppm}: \delta 4.6(\mathrm{~s}$, $2 \mathrm{H}, \mathrm{NH}_{2} \mathrm{D}_{2} \mathrm{O}$ exchangeable), $\delta 7.18(\mathrm{~s}, 1 \mathrm{H}, \mathrm{Ar} \mathrm{H}), \delta 7.29(\mathrm{~s}, 1 \mathrm{H}$, Ar $\mathrm{H}$ ), and $\delta 9.3$ (s, 1H, NH D $2 \mathrm{O}$ exchangeable); ${ }^{13} \mathrm{C} \mathrm{NMR}$ $\left(\mathrm{DMSO}-d_{6}\right): \delta 108.9,116.4,123.4,130.09,130.66,139.2$, and 153.8; MS: $\left(\mathrm{M}^{+}\right) \mathrm{m} / z$ 218, $m / z^{+2} 220$, and $m / z^{+4} 222$; Anal. Calcd for $\mathrm{C}_{7} \mathrm{H}_{5} \mathrm{Cl}_{2} \mathrm{~N}_{3} \mathrm{O}$ (218.04): C 38.56, $\mathrm{H}$ 2.31, and N 19.27; Found: C 38.53, H 2.30, and N 19.25.

(v) Preparation of 6,8-Dichloro[1,2,4]triazolo[3,4-b][1,3]benzoxazole (4). The mixture of compound 3 (10 mmol), Formic acid $(10 \mathrm{~mL})$ and catalytic amount of concentrated Hydrochloric acid was heated under reflux for $5 \mathrm{hr}$. The reaction mixture was allowed to cool to room temperature and poured onto water $(50 \mathrm{~mL})$. The obtained solid was filtered, washed with ethanol, dried and recrystallized using methanol.

Half white solid; IR (KBr) $\nu_{\max } \mathrm{cm}^{-1}: 1627(\mathrm{C}=\mathrm{N}), 1459$ $(\mathrm{C}=\mathrm{C})$, and $748(\mathrm{C}-\mathrm{Cl}) ;{ }^{1} \mathrm{H}$ NMR (DMSO- $\left.d_{6}\right)$ ppm: $\delta 7.17$ (s, $1 \mathrm{H}, \operatorname{Ar} \mathrm{H}), \delta 7.35$ (s, $1 \mathrm{H}, \mathrm{Ar} \mathrm{H})$, and $\delta 12.18(\mathrm{~s}, 1 \mathrm{H},=\mathrm{CH})$; ${ }^{13} \mathrm{C}$ NMR (DMSO- $d_{6}$ ): $\delta 111.2,115.5,117.3,122.9,130.2,132.23$, 141.9, and 155.9; MS: $\left(\mathrm{M}^{+}\right) m / z 228, m / z^{+2} 230$, and $m / z^{+4} 232$; Anal. Calcd for $\mathrm{C}_{8} \mathrm{H}_{3} \mathrm{Cl}_{2} \mathrm{~N}_{3} \mathrm{O}$ (228.04): $\mathrm{C} 42.14, \mathrm{H} 1.33$, and $\mathrm{N}$ 18.43; Found: C 42.11, H 1.30, and N 18.42.

(vi) Preparation of 2-Dichloroquinoline-3-carbaldehyde(5,7dichloro-1,3-benzoxazol-2-yl)hydrazone 7a. The compound 4 $(0.01 \mathrm{~mol})$ and compound $\mathbf{6 a}(0.01 \mathrm{~mol})$ were taken in water and refluxed for $4 \mathrm{~h}$. The completion of the reaction was monitored by TLC. Then, the reaction mixture was cooled and filtered. The obtained solid $7 \mathbf{a}$ was recrystallized from ethyl acetate.

The compounds $\mathbf{7 ( b - f )}$ were prepared by using a similar procedure.

(vii) Preparation of 1-(5,7-Dichloro-1,3-benzoxazol-2-yl)-1Hpyrazolo[3,4-b]quinoline $8 \boldsymbol{a}$. To the compound $7 \mathbf{a}(0.5 \mathrm{gm})$, a pinch of P-TSA was added. The reaction mass was taken in DMF $(15 \mathrm{~mL})$ and refluxed for $3 \mathrm{~h}$. The completion of the reaction was monitored by TLC. Then, the reaction mixture was cooled and filtered. The obtained solid 8a was recrystallized from ethanol.

The compounds $\mathbf{8}(\mathbf{b}-\mathbf{f})$ were prepared by a similar method.

The physical data of newly synthesized compounds $\mathbf{8}(\mathbf{a}-$ f) are tabulated in Table 1.

1-(5,7-Dichloro-1,3-benzoxazol-2-yl)-1H-pyrazolo[3,4-b]quinoline (8a). IR (KBr) $v_{\max } \mathrm{cm}^{-1}: 1619(\mathrm{C}=\mathrm{N}), 1455(\mathrm{C}=\mathrm{C})$, $758\left(\mathrm{C}-\mathrm{Cl} ;{ }^{1} \mathrm{H}\right.$ NMR $\left(400 \mathrm{MHz}, \mathrm{DMSO}-d_{6}\right)$ ppm: $\delta 7.26-8.1$ $(7 \mathrm{H}, \mathrm{Ar} \mathrm{H})$, and $\delta 9.06$ (s, $1 \mathrm{H}, \mathrm{pyr}) ;{ }^{13} \mathrm{C} \mathrm{NMR}(100 \mathrm{MHz}$, DMSO- $d_{6}$ ): $\delta$ 107-161 (17 Ar-C); $M / z 355, M^{+2} 357$, and $M^{+4}$ 359. 
TABLE 1: Physical data of the compounds $\mathbf{8}(\mathbf{a}-\mathbf{f})$.

\begin{tabular}{lcccccccc}
\hline \multirow{2}{*}{ Comp } & \multirow{2}{*}{ Molecular formula } & \multirow{2}{*}{ Molecular weight } & \multirow{2}{*}{ Appearance } & \multirow{2}{*}{ M.P. $\left({ }^{\circ} \mathrm{C}\right)$} & \multirow{2}{*}{ Yield (\%) } & \multicolumn{3}{c}{ Elemental analysis found (calc.) \% } \\
& & & & & & $\mathrm{C}$ & $\mathrm{N}$ \\
\hline $\mathbf{8 a}$ & $\mathrm{C}_{17} \mathrm{H}_{8} \mathrm{Cl}_{2} \mathrm{~N}_{4} \mathrm{O}$ & 355.17 & Solid & $171-174$ & 87 & $57.47(57.49)$ & $2.25(2.27)$ & $15.79(15.77)$ \\
$\mathbf{8 b}$ & $\mathrm{C}_{18} \mathrm{H}_{10} \mathrm{Cl}_{2} \mathrm{~N}_{4} \mathrm{O}$ & 369.20 & Solid & $187-190$ & 76 & $58.58(58.56)$ & $2.77(2.73)$ & $15.15(15.18)$ \\
$\mathbf{8 c}$ & $\mathrm{C}_{17} \mathrm{H}_{7} \mathrm{BrCl}_{2} \mathrm{~N}_{4} \mathrm{O}$ & 434.07 & Solid & $166-168$ & 79 & $47.01(47.04)$ & $1.61(1.63)$ & $12.95(12.91)$ \\
$\mathbf{8 d}$ & $\mathrm{C}_{17} \mathrm{H}_{7} \mathrm{Cl}_{3} \mathrm{~N}_{4} \mathrm{O}$ & 389.62 & Solid & $142-143$ & 85 & $52.44(52.41)$ & $1.82(1.81)$ & $14.34(14.38)$ \\
$\mathbf{8 e}$ & $\mathrm{C}_{18} \mathrm{H}_{10} \mathrm{Cl}_{2} \mathrm{~N}_{4} \mathrm{O}_{2}$ & 385.20 & Solid & $155-156$ & 86 & $51.05(51.02)$ & $1.73(1.76)$ & $17.52(17.50)$ \\
$\mathbf{8 f}$ & $\mathrm{C}_{17} \mathrm{H}_{8} \mathrm{Cl}_{2} \mathrm{~N}_{4} \mathrm{O}_{2}$ & 371.17 & Solid & $178-181$ & 80 & $55.03(55.01)$ & $2.15(2.17)$ & $15.07(15.09)$ \\
\hline
\end{tabular}

1-(5,7-Dichloro-1,3-benzoxazol-2-yl)-6-methyl-1H-pyrazolo[3, 4-b]quinoline (8b). IR ( $\mathrm{KBr}) v_{\max } \mathrm{cm}^{-1}: 3010\left(-\mathrm{CH}_{3}\right), 1660$ $(\mathrm{C}=\mathrm{N})$, and $1440(\mathrm{C}=\mathrm{C}) ;{ }^{1} \mathrm{H}$ NMR $\left(400 \mathrm{MHz}, \mathrm{DMSO}-d_{6}\right)$ ppm: $\delta 2.4\left(\mathrm{~s}, 3 \mathrm{H}, \mathrm{CH}_{3}\right), \delta 7.2-8.7(6 \mathrm{H}, \mathrm{Ar} \mathrm{H})$, and $\delta 9.04$ (s, $1 \mathrm{H}, \mathrm{pyr}) ;{ }^{13} \mathrm{C}$ NMR $\left(100 \mathrm{MHz}, \mathrm{DMSO}-d_{6}\right): \delta$ 107-161 (17 Ar-C), and 9.9 (methyl); $M / z 369, M^{+2} 371$, and $M^{+4} 373$.

6-Bromo-1-(5,7-dichloro-1,3-benzoxazol-2-yl)-1H-pyrazolo[3,4b]quinoline (8c). IR (KBr) $\nu_{\max } \mathrm{cm}^{-1}: 1640(\mathrm{C}=\mathrm{N}), 1470$ $(\mathrm{C}=\mathrm{C})$, and $800(\mathrm{C}-\mathrm{Cl}) ;{ }^{1} \mathrm{H}$ NMR $\left(400 \mathrm{MHz}, \mathrm{DMSO}-d_{6}\right)$ ppm: $\delta 7.0-8.3(6 \mathrm{H}, \mathrm{Ar} \mathrm{H})$, and $\delta 9.03$ (s, $1 \mathrm{H}, \mathrm{pyr}) ;{ }^{13} \mathrm{C}$ NMR $\left(100 \mathrm{MHz}, \mathrm{DMSO}-d_{6}\right): 107.72-161.5$ (17 Ar-C); $M / z$ 434, $M^{+2}$ 436 , and $M^{+4} 438$.

6-Chloro-1-(5,7-dichloro-1,3-benzoxazol-2-yl)-1H-pyrazolo[3, 4-b]quinoline (8d). IR ( $\mathrm{KBr}) v_{\max } \mathrm{cm}^{-1}: 31635(\mathrm{C}=\mathrm{N}), 1472$ $(\mathrm{C}=\mathrm{C}), 765(\mathrm{C}-\mathrm{Cl}) ;{ }^{1} \mathrm{H}$ NMR $\left(400 \mathrm{MHz}, \mathrm{DMSO}-d_{6}\right) \mathrm{ppm}$ : $\delta 7.2-8.2(6 \mathrm{H}, \mathrm{Ar} \mathrm{H})$, and $\delta 9.02(\mathrm{~s}, 1 \mathrm{H}, \mathrm{pyr}) ;{ }^{13} \mathrm{C} \mathrm{NMR}$ (100 MHz, DMSO- $d_{6}$ ): 107.71-161.4 (17 Ar-C); M/z 389, $M^{+2}$ 391, and $M^{+4} 393$.

1-(5,7-Dichloro-1,3-benzoxazol-2-yl)-6-methoxy-1H-pyrazolo[3, 4-b]quinoline (8e). IR ( $\mathrm{KBr}) v_{\max } \mathrm{cm}^{-1}: 3064\left(-\mathrm{OCH}_{3}\right), 1630$ $(\mathrm{C}=\mathrm{N}), 1471(\mathrm{C}=\mathrm{C})$, and $761(\mathrm{C}-\mathrm{Cl}) ;{ }^{1} \mathrm{H}$ NMR $(400 \mathrm{MHz}$, DMSO- $\left.d_{6}\right)$ ppm: $\delta 4.01\left(\mathrm{~s}, 3 \mathrm{H}, \mathrm{OCH}_{3}\right), 7.1-8.38(6 \mathrm{H}, \mathrm{Ar} \mathrm{H})$, and $\delta 9.01(\mathrm{~s}, 1 \mathrm{H}, \mathrm{pyr}) ;{ }^{13} \mathrm{C}$ NMR $\left(100 \mathrm{MHz}, \mathrm{DMSO}-d_{6}\right)$ : 107.8-161.6 (17 Ar-C), and 55.6 (methoxy); $M / z 385, M^{+2} 387$, and $M^{+4} 389$.

1-(5,7-Dichloro-1,3-benzoxazol-2-yl)-1H-pyrazolo[3,4-b]quinolin-6-ol (8f). IR ( $\mathrm{KBr}) v_{\max } \mathrm{cm}^{-1}: 3450(-\mathrm{OH}), 1640(\mathrm{C}=\mathrm{N})$, $1479(\mathrm{C}=\mathrm{C})$, and $757(\mathrm{C}-\mathrm{Cl}) ;{ }^{1} \mathrm{H}$ NMR (400 MHz, DMSO- $\left.d_{6}\right)$ ppm: and $\delta$ 7.27-8.75 (7H, Ar H, 1-OH, $\delta 9.03$ (s, $1 \mathrm{H}$, pyr); ${ }^{13} \mathrm{C}$ NMR (100 MHz, DMSO- $\left.d_{6}\right)$ : 107.70-161.22 (17 Ar-C); $M / z 371, M^{+2} 373$, and $M^{+4} 375$.

2.2. Antibacterial Activity. The antibacterial efficacy of the compounds was tested by using agar well diffusion method [14]. The $24 \mathrm{hr}$ old Mueller-Hinton broth cultures of test bacteria were swabbed on sterile Mueller-Hinton agar plates using sterile cotton swab followed by punching wells of $6 \mathrm{~mm}$ with the help of sterile cork borer. The standard drug (chloramphenicol, $1 \mathrm{mg} / \mathrm{mL}$ of sterile distilled water), compounds $\mathbf{8}(\mathbf{a}-\mathbf{f})(20 \mathrm{mg} / \mathrm{mL}$ of $10 \%$ DMSO$)$, and control (10\% DMSO) were added to the respectively labeled wells. The plates were allowed to stand for 30 minutes and were incubated at $37^{\circ} \mathrm{C}$ for $24 \mathrm{hr}$ in upright position, and the zone of inhibition was recorded.

\subsection{Antioxidant Activity}

2.3.1. DPPH Assay. The radical scavenging ability of synthesized compounds and the ascorbic acid (standard) was tested on the basis of radical scavenging effect on a DPPHfree radical. Different concentrations $(25,50,100,200$, and $400 \mu \mathrm{g} / \mathrm{mL}$ ) of compounds and standard were prepared in methanol. In clean and labeled test tubes, $2 \mathrm{~mL}$ of DPPH solution $(0.002 \%$ in methanol) was mixed with $2 \mathrm{~mL}$ of different concentrations of compounds and standard separately. The tubes were incubated at room temperature in dark for $30 \mathrm{~min}$ utes, and the optical density was measured at $517 \mathrm{~nm}$ using UV-Visible Spectrophotometer. The absorbance of the DPPH control was also noted. The scavenging activity was calculated using the formula: scavenging activity $(\%)=A-B / A \times 100$, where $A$ is the absorbance of DPPH and $B$ is the absorbance of DPPH in standard combination [15].

2.3.2. Ferric Reducing Assay. Different concentrations (25, 50, 100,200 , and $400 \mu \mathrm{g} / \mathrm{mL}$ ) of compounds and standard (tannic acid) in $1 \mathrm{~mL}$ of methanol were mixed in separate tubes with $2.5 \mathrm{~mL}$ of phosphate buffer $(200 \mathrm{mM}, \mathrm{pH} 6.6)$ and $2.5 \mathrm{~mL}$ of $1 \%$ potassium ferricyanide. The tubes were placed in water bath for 20 minutes at $50^{\circ} \mathrm{C}$, cooled rapidly, and mixed with $2.5 \mathrm{~mL}$ of $10 \%$ trichloroacetic acid and $0.5 \mathrm{~mL}$ of $0.1 \%$ ferric chloride. The amount of iron (II)-ferricyanide complex formed was determined by measuring the formation of Perl's Prussian blue at $700 \mathrm{~nm}$ after 10 minutes. The increase in absorbance of the reaction mixture indicated the increased reducing power [16].

\section{Results and Discussion}

3.1. Chemistry. To begin our work, it was planned to synthesize the acetyl hydrazide $\mathbf{3 a}$ as an intermediate compound. From compound $\mathbf{3 a}$, it was planned to construct some heterocyclic compounds, but from spectroscopic determination it was evident that the obtained compound was $\mathbf{4}$, not $\mathbf{3 a}$. Recent literature survey [17] also confirmed the formation of compound 4 from 2a. The mechanism of formation of the compound $\mathbf{4}$ from 2a is represented in Scheme 1.

Satyendra et al. [18] reported the synthetic route of compound 4 in above mentioned procedure. It is possible 


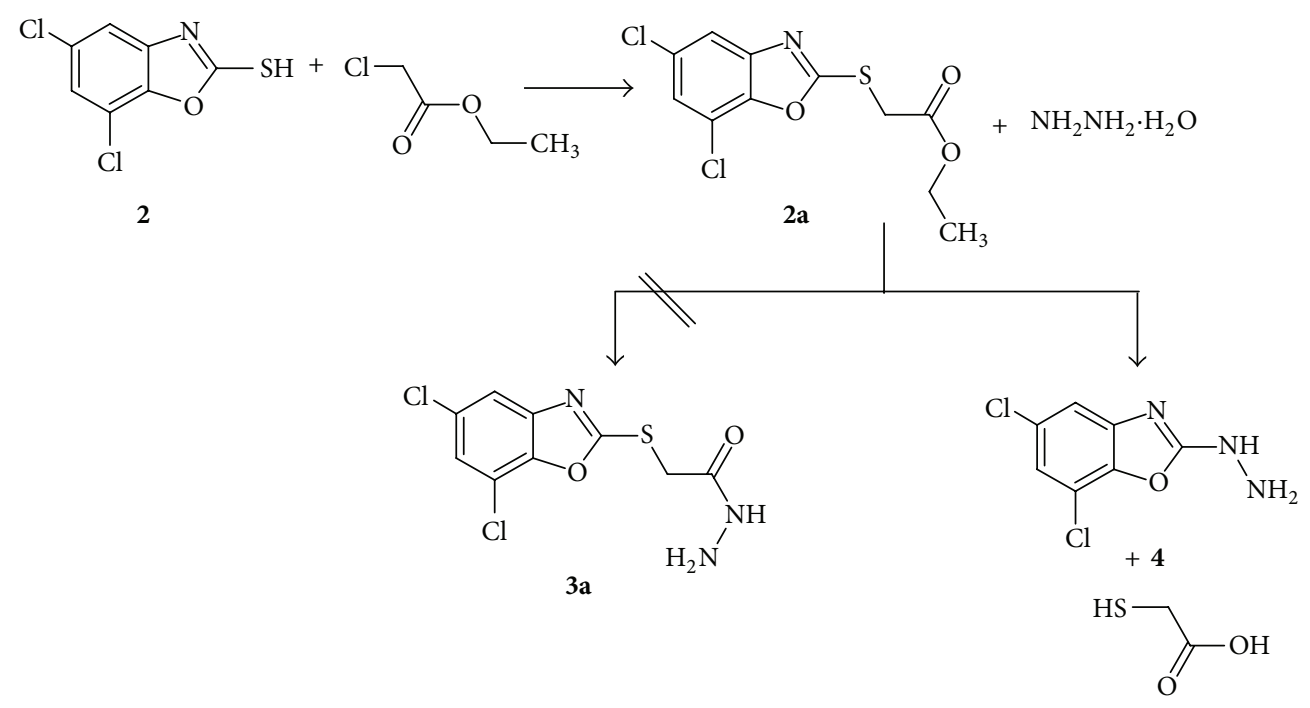

SCHEME 1<smiles>Nc1cc(Cl)cc(Cl)c1O</smiles><smiles>Sc1nc2cc(Cl)cc(Cl)c2o1</smiles>

1

2<smiles>CCOS(=O)(=O)CN(N)C(=O)O</smiles>

3<smiles></smiles>

4

Scheme 2: Synthetic route for compound 4.

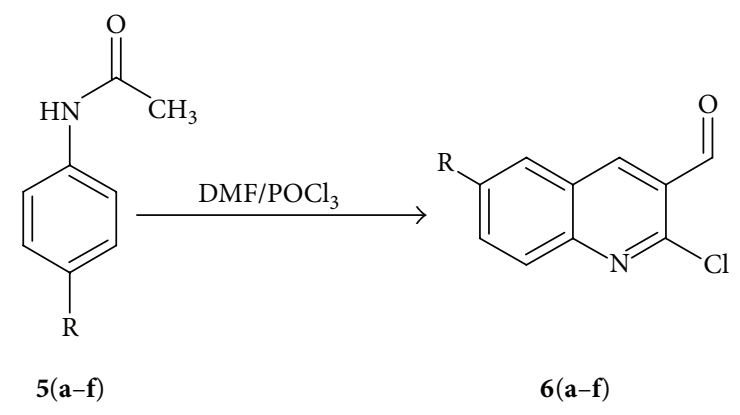

Scheme 3: Synthetic route for compounds $\mathbf{6}(\mathbf{a}-\mathbf{f})$.

to synthesize the 5,7-dichloro-2-hydrazino-1,3-benzoxazole 4 by direct method as mentioned in Scheme 2. The mercapto compound 2 was reacted with ethyl iodide produced ethylthiobenzoxazole 3 , followed by the reaction with hydrazine hydrate; this yielded 5,7-dichloro-2-hydrazino-1,3benzoxazole 4 .

In both methods, the formed compound was found to be the same, which was confirmed by elemental analysis, melting point determination, and spectral studies. In Scheme 2, the compound obtained in high yield and also the time taken for the completion of reaction were found to be less. The compounds $\mathbf{6}(\mathbf{a}-\mathbf{f})$ synthesized as per literature and mentioned in Scheme 3.

In the present work, the synthesis of some novel, fused heterocyclic compounds containing benzoxazole and quinoline nucleus has been constructed (Scheme 4). The target molecules are characterized by IR, ${ }^{1} \mathrm{H}$ NMR, ${ }^{13} \mathrm{C}$ NMR, and mass spectroscopic analysis. In this work, we have tried to get the target molecule according to reported procedure, but cyclization does not take place. The chromatogram for the compounds $7 \mathbf{a}$ and $\mathbf{7 b}$ showed peak at 391, 395 and 405, 409, respectively. So, the compounds $7(\mathbf{a}-\mathbf{f})$ were taken for the next step on the basis of the obtained spectral data. Once 


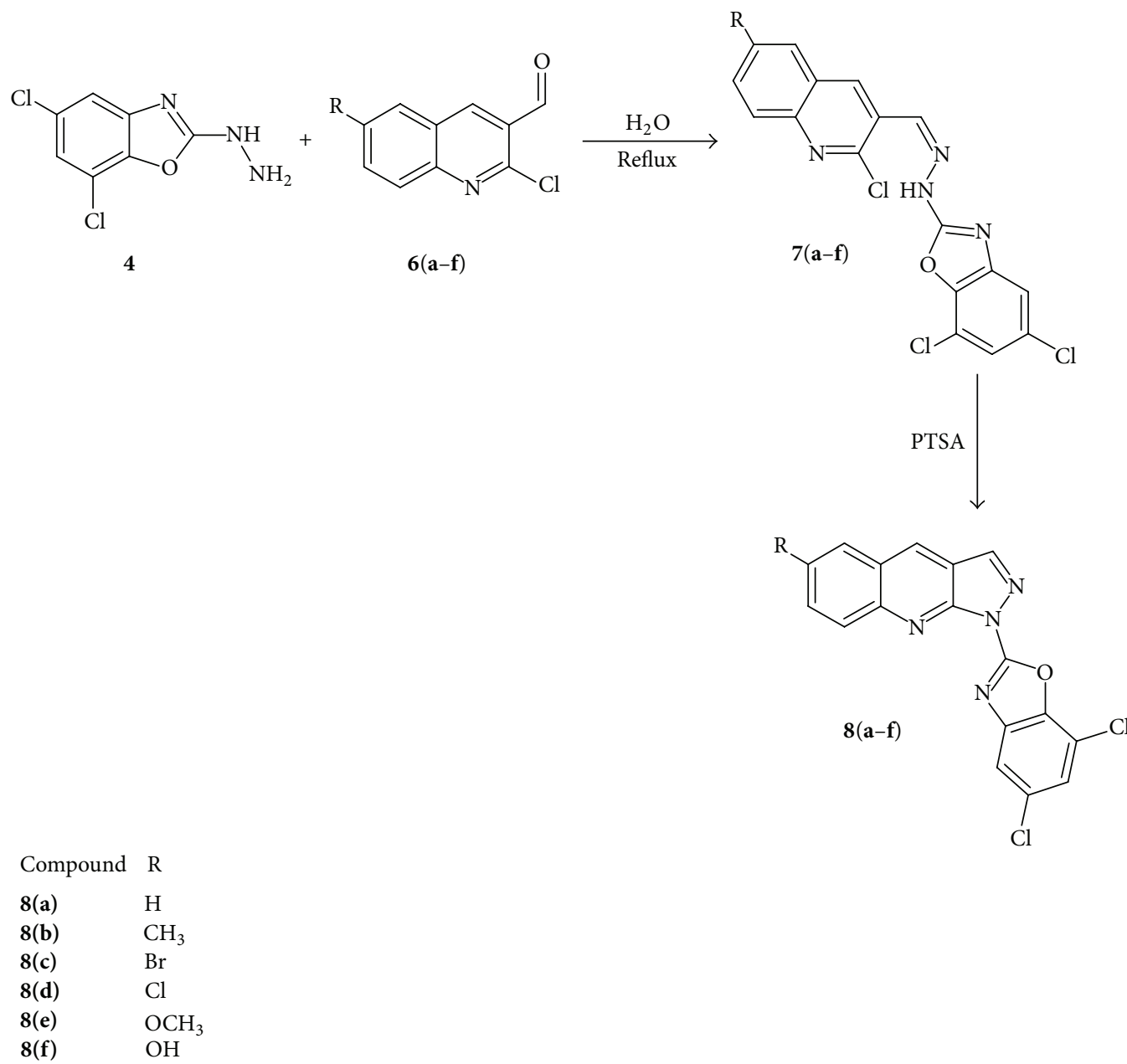

Scheme 4: Synthetic route for Compounds $8(\mathbf{a}-\mathbf{f})$.

again, the reaction was continued further to get the cyclized product using PTSA as catalyst.

The molecules $\mathbf{8}(\mathbf{a}-\mathbf{f})$ showed the absence of $-\mathrm{NH}$ peak in their IR, and the disappearance of $-\mathrm{NH}$ in ${ }^{1} \mathrm{H}$ NMR spectrum evidenced the cyclization of the product. In the IR spectrum, the stretching frequency at $3367 \mathrm{~cm}^{-1}$ disappeared, and also there is no stretching frequency for 2-chloroformyl quinoline at $1721 \mathrm{~cm}^{-1}$. A peak at $\delta 9.3$ for a proton of $-\mathrm{NH}$ disappeared, and new peaks were observed at the aromatic region. The signals obtained for aromatic protons at $\delta 7.2-8.1(\mathrm{~m}, 7 \mathrm{Ar}$ $\mathrm{H}$ ) and a singlet at $\delta 9.06$ for $-\mathrm{N}=\mathrm{CH}$ strongly supported the formation of the product. Mass spectrum gives peak at $M^{+} 355, M^{+2} 357$, and $M^{+4} 359$ corresponds to its molecular weight. The new signal at 161 in ${ }^{13} \mathrm{C}$ NMR corresponds to $-\mathrm{N}=\mathrm{CH}$ carbon atom. The signals at $\delta 2.5$ for the compound $\mathbf{8 b}$ and $\delta 4.0$ for the compound $\mathbf{8 e}$ in the ${ }^{1} \mathrm{H}$ NMR spectrum also evidenced the formation of derivatives for corresponding molecule.

\subsection{Biological Evaluation}

3.2.1. Antibacterial Activity. The antimicrobial activity was tested against bacterial strains by agar well diffusion method.
The compounds $\mathbf{8 a}$ and $\mathbf{8 e}$ exhibit potent antibacterial activity, whereas the compound $\mathbf{8 c}$ showed promising antibacterial activity. The results were tabulated in Table 2 .

3.2.2. Antioxidant Activity. The antioxidant activity at different concentrations, namely, 25, 50, 100, 200, and $400 \mu \mathrm{g} / \mathrm{mL}$, of the compounds $\mathbf{8}(\mathbf{a}-\mathbf{f})$ and ascorbic acid was tested on the basis of the radical scavenging effect of the stable DPPH free radical assay. The compound $\mathbf{8 f}$ showed better radical scavenging activity followed by the compound $\mathbf{8 e}$ (Figure 1 ). The obtained results were recorded in Table 3 .

The result of reducing power at different concentrations of compounds $\mathbf{8}(\mathbf{a}-\mathbf{f})$ and tannic acid is represented in Table 4. In this study, the absorbance was found to increase with the dose of compounds and standard, which is suggestive of reducing power (Figure 2). The compounds $8 \mathbf{e}$ and $\mathbf{8 f}$ showed remarkable reducing power.

\section{Conclusion}

The formation of pyrazole moiety with fused benzoxazole and quinoline moiety was achieved by using PTSA as a catalyst. The obtained target molecules were characterized by using 
TABLE 2: Antibacterial activity of compounds $8(\mathbf{a}-\mathbf{f})$.

\begin{tabular}{|c|c|c|c|c|c|c|c|}
\hline \multirow{2}{*}{ Compound } & \multicolumn{7}{|c|}{ Diameter of zone of inhibition in $\mathrm{cm}$} \\
\hline & V. cholera & S. aureus & K. pneumoniae & P. aeruginosa & B. cereus & E. coli & S. flexneri \\
\hline $8 \mathbf{a}$ & 2.5 & 2.6 & 2.8 & 2.6 & 2.8 & 2.8 & 2.5 \\
\hline $8 b$ & 1.2 & 1.4 & 1.4 & 1.3 & 1.5 & 1.2 & 1.2 \\
\hline $8 c$ & 2.1 & 2.5 & 2.5 & 2.4 & 2.5 & 2.6 & 2.2 \\
\hline $8 d$ & 1.0 & 1.5 & 1.3 & 1.4 & 1.6 & 1.2 & 1.1 \\
\hline $8 \mathrm{e}$ & 2.4 & 2.3 & 2.6 & 2.4 & 2.7 & 2.6 & 2.6 \\
\hline $8 f$ & 1.0 & 1.3 & 1.2 & 1.1 & 1.5 & 1.1 & 1.0 \\
\hline Control & 0 & 0 & 0 & 0 & 0 & 0 & 0 \\
\hline Standard & 2.8 & 2.7 & 3.1 & 2.8 & 2.9 & 3.0 & 2.8 \\
\hline
\end{tabular}

Standard drug: bacteria (Ciprofloxacin); compounds: ( $1 \mathrm{mg} / \mathrm{mL})$; control: DMSO (dimethyl sulphoxide); and sample used: synthetic compounds.

TABLE 3: DPPH radical scavenging activity of compounds $\mathbf{8}(\mathbf{a}-\mathbf{f})$.

\begin{tabular}{|c|c|c|c|c|c|}
\hline \multirow{2}{*}{ Compound } & \multicolumn{5}{|c|}{ Scavenging activity of different concentrations $(\mu \mathrm{g} / \mathrm{mL})$ of compounds $\%$} \\
\hline & 25 & 50 & 100 & 200 & 400 \\
\hline $8 \mathbf{a}$ & 28.95 & 35.80 & 42.89 & 48.60 & 54.95 \\
\hline $8 \mathbf{b}$ & 26.65 & 33.25 & 40.79 & 45.10 & 52.35 \\
\hline $8 \mathrm{c}$ & 31.35 & 38.09 & 42.70 & 48.95 & 53.18 \\
\hline $8 d$ & 38.15 & 45.45 & 48.30 & 54.60 & 59.90 \\
\hline $8 \mathrm{e}$ & 49.95 & 58.50 & 63.60 & 71.35 & 76.30 \\
\hline $8 f$ & 59.21 & 63.74 & 67.57 & 74.43 & 78.70 \\
\hline Ascorbic acid & 82.51 & 87.24 & 92.63 & 94.28 & 97.34 \\
\hline
\end{tabular}

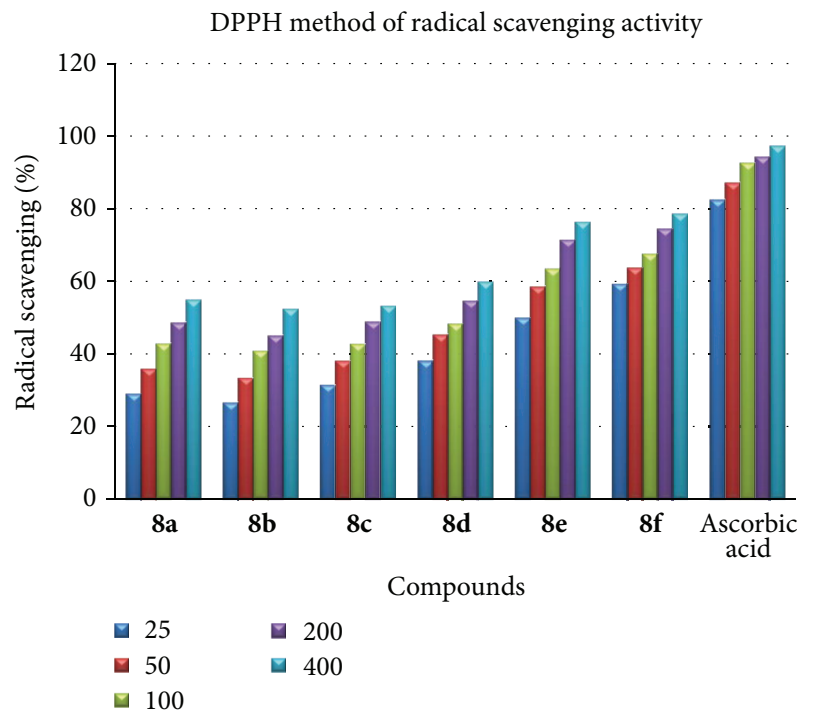

Figure 1: DPPH method of radical scavenging activity.

spectral data. The synthesized compounds were screened for antibacterial and antioxidant activities. The results revealed that, among the title compounds, the compounds $\mathbf{8 a}$ and 8e showed higher inhibition while the other compounds displayed moderate to low inhibition. In case of antioxidant activity, the compounds $\mathbf{8 e}$ and $\mathbf{8 f}$ exhibited effective

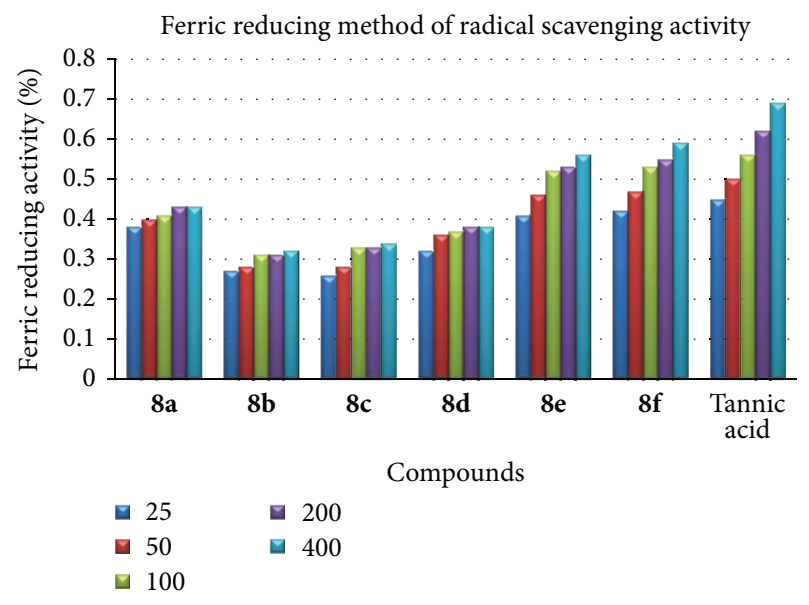

FIGURE 2: Ferric reducing Method of radical scavenging activity.

scavenging as well as ferric reducing activity, while compounds $8 \mathbf{a}, \mathbf{8 c}$, and $8 \mathbf{d}$ have shown moderate activity.

\section{Acknowledgment}

The author (N. D. Jayanna) is grateful to the UGC for providing Rajiv Gandhi Research Fellowship. The authors are thankful to the Director, IISc, Bangalore, for providing spectral data and are thankful to the Principal, Sahyadri 
TABLE 4: Ferric reducing activity of compounds $8(\mathbf{a}-\mathbf{f})$.

\begin{tabular}{|c|c|c|c|c|c|}
\hline \multirow{2}{*}{ Compound } & \multicolumn{5}{|c|}{ Ferric reducing activity of different concentrations $(\mu \mathrm{g} / \mathrm{mL}) \%$} \\
\hline & 25 & 50 & 100 & 200 & 400 \\
\hline $8 \mathbf{a}$ & 0.38 & 0.40 & 0.41 & 0.43 & 0.43 \\
\hline $8 \mathbf{b}$ & 0.27 & 0.28 & 0.31 & 0.31 & 0.32 \\
\hline $8 c$ & 0.26 & 0.28 & 0.33 & 0.33 & 0.34 \\
\hline $8 d$ & 0.32 & 0.36 & 0.37 & 0.38 & 0.38 \\
\hline $8 \mathrm{e}$ & 0.41 & 0.46 & 0.52 & 0.53 & 0.56 \\
\hline $8 f$ & 0.42 & 0.47 & 0.53 & 0.55 & 0.59 \\
\hline Tannic acid & 0.45 & 0.50 & 0.56 & 0.62 & 0.69 \\
\hline
\end{tabular}

Science College, Shimoga, for providing laboratory facilities to carry out research work.

\section{References}

[1] T. Ertan, I. Yildiz, B. Tekiner-Gulbas et al., "Synthesis, biological evaluation and 2D-QSAR analysis of benzoxazoles as antimicrobial agents," European Journal of Medicinal Chemistry, vol. 44, no. 2, pp. 501-510, 2009.

[2] C. Ramalingan, S. Balasubramanian, S. Kabilan, and M. Vasudevan, "Synthesis and study of antibacterial and antifungal activities of novel 1-[2-(benzoxazol-2-yl)ethoxy]- 2,6diarylpiperidin-4-ones," European Journal of Medicinal Chemistry, vol. 39, no. 6, pp. 527-533, 2004.

[3] G. Turan-Zitouni, Ş. Demirayak, A. Özdemir, Z. A. Kaplancikli, and M. T. Yildiz, "Synthesis of some 2-[(benzazole-2yl)thioacetylamino] thiazole derivatives and their antimicrobial activity and toxicity," European Journal of Medicinal Chemistry, vol. 39, no. 3, pp. 267-272, 2004.

[4] O. Temiz, I. Oren, E. A. Sener, I. Yalcin, and N. Ucartuerk, "Synthesis and microbiological activity of some novel 5- or 6methyl-2-(2,4-disubstituted phenyl) benzoxazole derivatives," Farmaco, vol. 53, no. 5, pp. 337-341, 1998.

[5] I. Ören, Ö. Temiz, I. Yalçin, E. Şener, and N. Altanlar, "Synthesis and antimicrobial activity of some novel 2,5- and/or 6-substituted benzoxazole and benzimidazole derivatives," European Journal of Pharmaceutical Sciences, vol. 7, no. 2, pp. 153-160, 1999.

[6] B. Shrivastava, V. Sharma, and P. Lokwani, "Be zoxazole: the ucleus of diverse biological activities," Pharmacologyonline, vol. 1, pp. 236-245, 2011.

[7] E. A. Charles, V. K. Agrawal, S. Sharma, and R. N. Iyer, "Synthesis of 2,5-disubstituted benzimidazoles as potential antihookworm and antimicrobial agents European," Journal of Medicinal Chemistry-Chimica Therapeutica, vol. 5, pp. 435-443, 1979.

[8] X.-H. Liu, P. Cui, B.-A. Song, P. S. Bhadury, H.-L. Zhu, and S.-F. Wang, "Synthesis, structure and antibacterial activity of novel 1-(5-substituted-3-substituted-4,5-dihydropyrazol1-yl)ethanone oxime ester derivatives," Bioorganic and Medicinal Chemistry, vol. 16, no. 7, pp. 4075-4082, 2008.

[9] A. Shi, T. A. Nguyen, S. K. Battina et al., "Synthesis and antibreast cancer activities of substituted quinolines," Bioorganic and Medicinal Chemistry Letters, vol. 18, no. 11, pp. 3364-3368, 2008.

[10] S. T. Selvi, V. Nadaraj, S. Mohan, R. Sasi, and M. Hema, "Solvent free microwave synthesis and evaluation of antimicrobial activity of pyrimido[4,5- $b]$ - and pyrazolo[3,4-b]quinolines,"
Bioorganic and Medicinal Chemistry, vol. 14, no. 11, pp. 38963903, 2006.

[11] S. P. Rajendran, M. Manonmani, and S. Vijayalakshmi, "Synthiesis of Pyrazolo (3, 4-b)quinolines and their 1-phenyl derivatives," Organic Preparation Procedures International, vol. 26, pp. 384-387, 1994.

[12] S. Paul, M. Gupta, R. Gupta, and A. Loupy, "Microwave assisted solvent-free synthesis of pyrazolo[3,4-b]quinolines and pyrazolo[3,4-c]pyrazoles using p-TsOH," Tetrahedron Letters, vol. 42, no. 23, pp. 3827-3829, 2001.

[13] A. Srivatsava and R. M. Singh, "Vilsmeier-Haack reagent: a facile synthesis of 2-chloro-3-formylquinolines from $\mathrm{N}$ arylacetamides and transformation into different functionalities," Indian Journal of Chemistry, vol. 44, pp. 1868-1875, 2005.

[14] B. Tepe, E. Donmez, M. Unlu et al., "Antimicrobial and antioxidative activities of the essential oils and methanol extracts of Salvia cryptantha (Montbret et Aucher ex Benth.) and Salvia multicaulis (Vahl)," Food Chemistry, vol. 84, no. 4, pp. 519-525, 2004.

[15] F. Hasan, A. A. Shah, and A. Hameed, "Methods for detection and characterization of lipases: a comprehensive review," Biotechnology Advances, vol. 27, no. 6, pp. 782-798, 2009.

[16] Y. S. Ravikumar, K. M. Mahadevan, M. N. Kumaraswamy et al., "Antioxidant, cytotoxic and genotoxic evaluation of alcoholic extract of Polyalthia cerasoides (Roxb.) Bedd," Environmental Toxicology and Pharmacology, vol. 26, no. 2, pp. 142-146, 2008.

[17] Y. Zhang, R. Z. Qiao, C. F. Dai, P. F. Xu, and Z. Y. Zhang, "The rearrangement of 2-benzothiazolylthioacetyl hydrazide in synthesis of s-triazolo[3, 4-b]benzothiazole-3-thiol," Chinese Chemical Letters, vol. 13, no. 4, pp. 287-289, 2002.

[18] R. V. Satyendra, K. A. Vishnumurthy, H. M. Vagdevi, K. P. Rajesh, H. Manjunatha, and A. Shruthi, "Synthesis, in vitro antioxidant, anthelmintic and molecular docking studies of novel dichloro substituted benzoxazole-triazolo-thione derivatives," European Journal of Medicinal Chemistry, vol. 46, no. 7, pp. 3078-3084, 2011. 

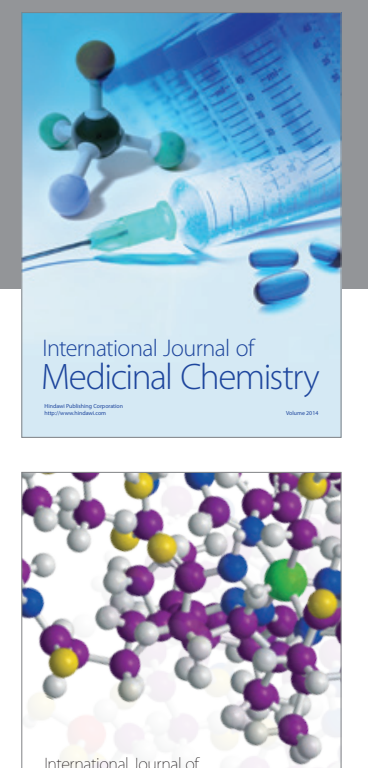

\section{Carbohydrate} Chemistry

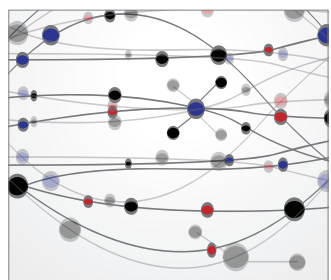

The Scientific World Journal
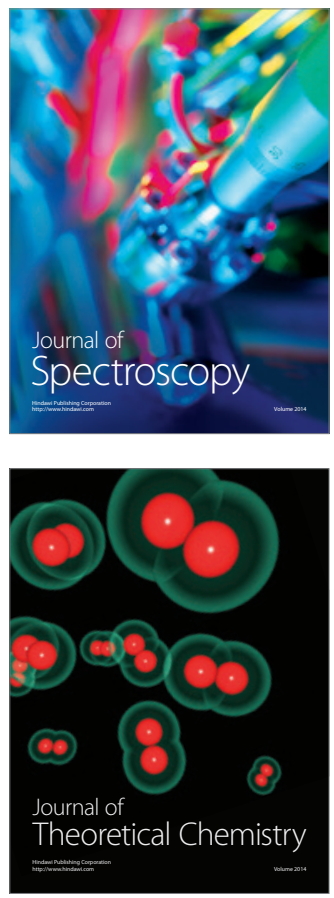
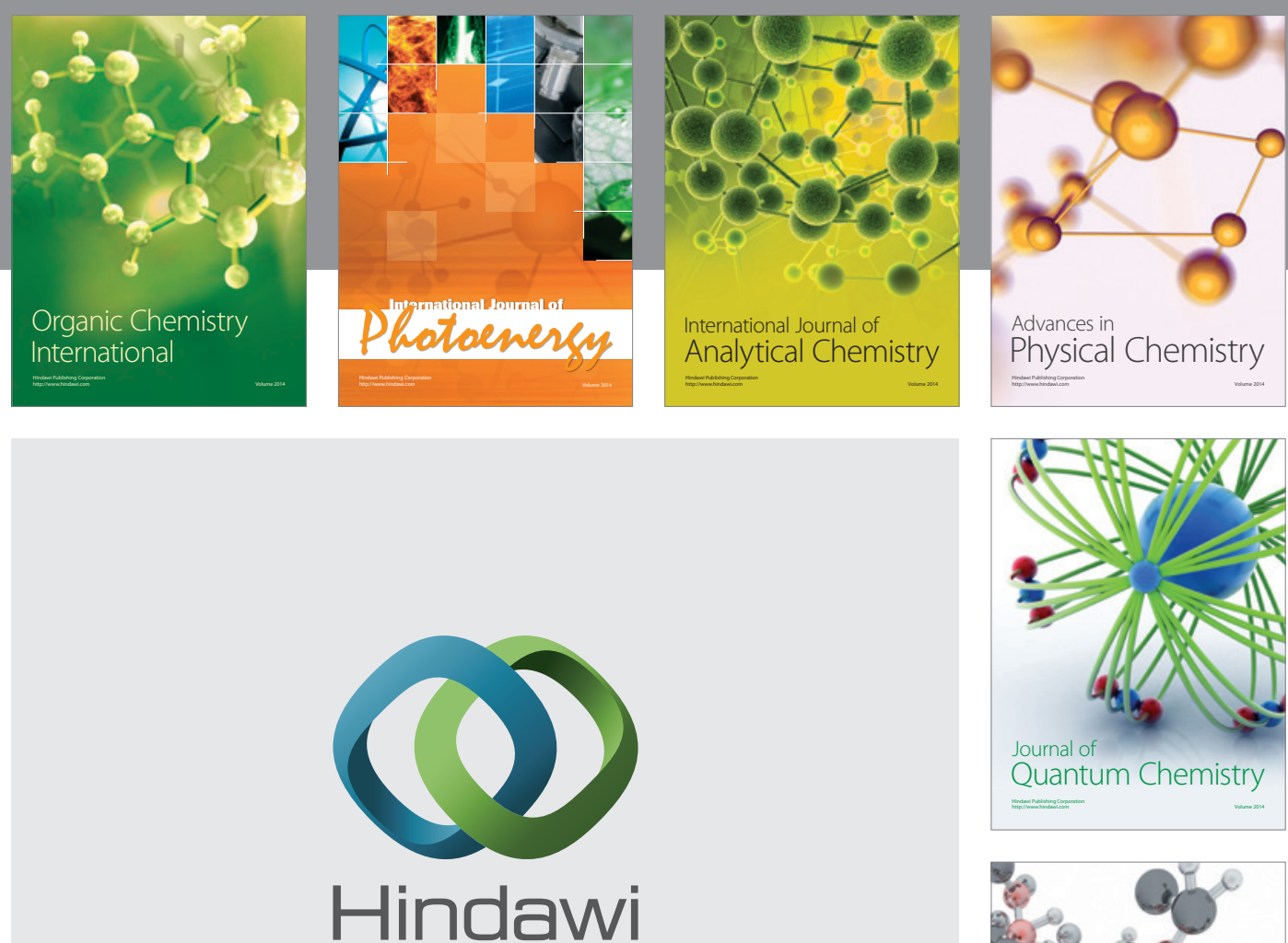

Submit your manuscripts at

http://www.hindawi.com

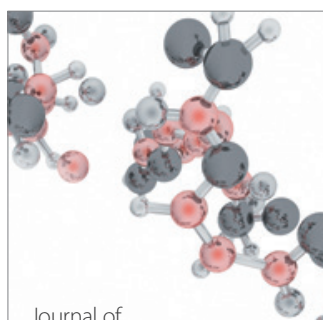

Analytical Methods

in Chemistry

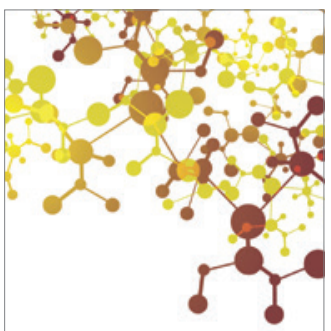

Journal of

Applied Chemistry

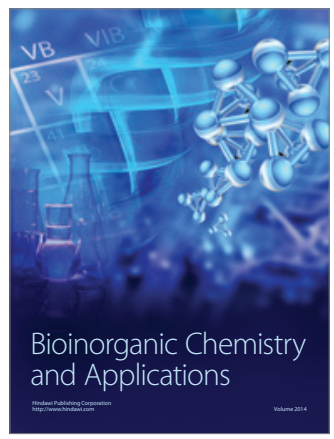

Inorganic Chemistry
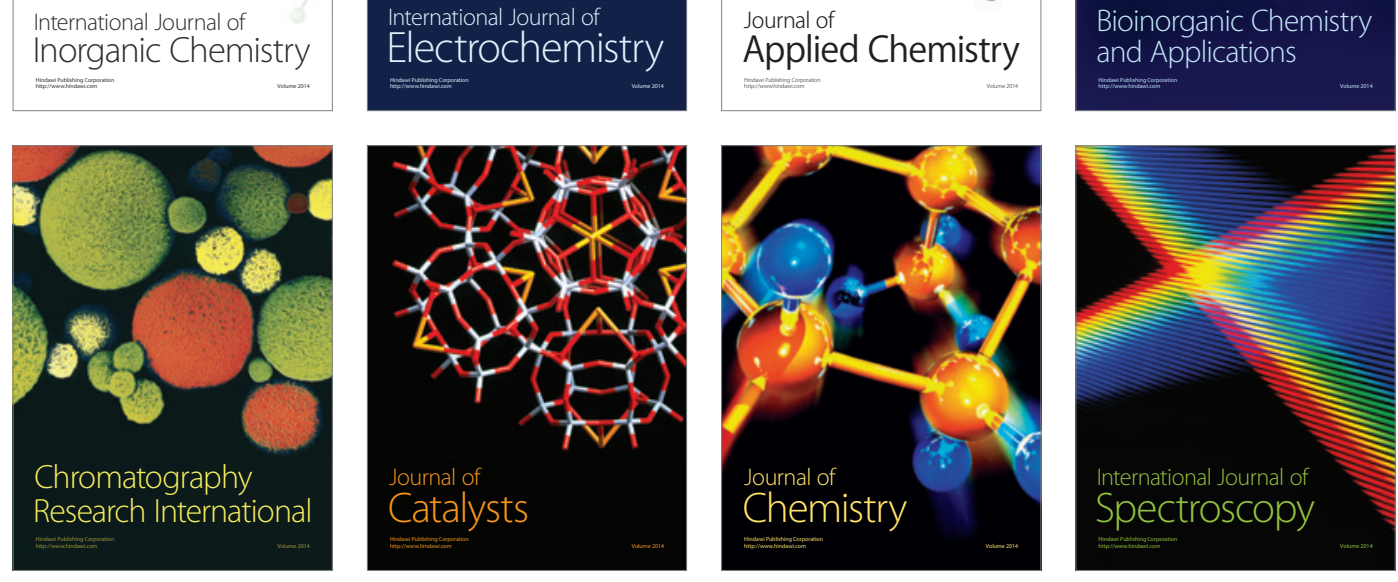